\title{
CHARACTERIZATION OF ZEA MAYS L. THROUGH MORPHOLOGICAL, BIOCHEMICAL AND MOLECULAR MARKERS
}

\author{
RAHIM, F. ${ }^{1 *}$-KHAN, M. Q. ${ }^{2}-$ ASHRAF, ${ }^{2}{ }^{2}-$ SHAFI, N. ${ }^{2}-$ KHAWAJA, S. $^{2}-$ KHALID, S. $^{2}-$ ZAHID, G. ${ }^{2}-$ \\ AHMED, M. ${ }^{1}-$ AHMED, M. S. ${ }^{3}$ \\ ${ }^{1}$ Department of Agriculture, Azad Jammu and Kashmir, Pakistan \\ (e-mail/phone: mumtaz.uel@googlemail.com/+92-333-513-7525-M. Ahmed) \\ ${ }^{2}$ University of Azad Jammu and Kashmir, Muzaffarabad, Pakistan \\ (e-mail/phone: mqkhan2004@yahoo.com/+92-344-581-7395-Q. Khan; \\ nasra.ashraf@yahoo.com/+92-347-328-2515 - N. Ashraf; \\ nuzhatshafi@gmail.com/+92-333-524-0171-N.Shafi; \\ sunduskh@yahoo.com/+92-334-572-8558-S. Khawaja; \\ sabaak01@yahoo.com/+92-335-538-6999-S. Khalid; \\ ghassanzahid@gmail.com/+92-334-509-3453-G. Zahid;) \\ ${ }^{3}$ Crop Science Institute, NARC, Islamabad, Pakistan \\ (e-mail/phone: ms.ahmedgenes@gmail.com/+92 321 5295691) \\ *Corresponding author \\ e-mail: sardarfaisalrahim@gmail.com; phone: +92-348-536-4771 \\ (Received $5^{\text {th }}$ Jan 2019 ; accepted $27^{\text {th }}$ Feb 2019)
}

\begin{abstract}
. 18 open-pollinated maize accessions were assessed for variability under randomized complete block design with 3 replications. Each plot comprised of two rows each $5 \mathrm{~m}$ in length with a plant to plant distance of $30 \mathrm{~cm}$ and a row to row distance of $75 \mathrm{~cm}$. Data on morpho-biochemical traits were collected and subjected to statistical analysis to find out the variability among the maize accessions and association of increasing protein and oil content with the agronomic traits. From the source population 5 varieties with a high percentage of oil and protein, were selected and analyzed for total seed protein profile using Sodium Dodecyl Sulphate Polyacrylamide Gel Electrophoresis. Significant results of variance and covariance were observed for all morpho-biochemical traits, which revealed significant variation among the maize accessions. SDS-PAGE showed considerable variation in protein banding among the maize accessions. Correlation results showed an independent association of morphological traits with oil and protein contents in almost all the source population. This indicated that oil and protein content of maize grain can be increased without negatively affecting the important agronomic traits. Based on the results, the variability could be utilized to develop commercial maize varieties with improved quality of grain utilizing the conventional techniques of selection and hybridization.
\end{abstract}

Keywords: biodiversity, correlation, oil content, protein content, SDS-PAGE

\section{Introduction}

Maize is the $3^{\text {rd }}$ most important crop in Pakistan after wheat and rice with an average yield of 4.3 ton ha ${ }^{-1}$ (Farooq, 2013) below the worldwide maize yield of 5.2 ton ha ${ }^{-1}$ (FAOSTAT, 2012). Therefore, it is very important to screen the new indigenous and exotic lines with an improved yield to be used in maize breeding programs (Iqbal et al., 2015). Genetic diversity is a basic tool for crop improvement (Iqbal et al., 2014) which could be managed, maintained and explained by morphological, biochemical and molecular markers (Vojka et al., 2016; Iqbal et al., 2015). 
Pakistan imports $75 \%$ of edible oil (Zaidi, 2014) and could save billions by promoting local edible oil. Besides carbohydrates corn grain also has a considerable percentage of oil (3.77 to 11.56\%) and protein (5.7 to 11.60\%) (Deif et al., 2012; Singh et al., 2005; Mittelmann et al., 2003; Okporie et al., 2002) and annually gives almost $15 \%$ of the proteins obtained from food-crops throughout the world ( $\mathrm{Li}$ and Vassal, 2004). Oil content and protein content of maize grain are positively associated with yield and its components (Sreckov, 2011; Obi and Onysishi, 1994), therefore, could be increased without adversely affecting yield (Okporie et al., 2007). Oil and protein of corn grain can be increased by different breeding techniques, e.g. recurrent selection method, which has been one of the most effective and successful methods used in breeding programs for maize improvement (Berner, et al., 2006; Uguru, 2005; Obi, 1991).

Many studies investigated variability among maize germplasm through morphological (Kariuki et al., 2016; Iqbal et al., 2015; Shrestha, 2014) and biochemical markers (Deif et al., 2012; Mittelmann et al., 2003). These experiments determined variability through morphological and biochemical characterization of maize varieties under RCBD with 3 replications and reported a wide range of variation for different morpho-biochemical characters investigated. Vojka et al. (2016) used morphological and molecular markers to study the variation among 29 inbred lines and reported that morphological and molecular markers are equally effective and accurate practices to determine the pedigree information of tested maize lines.

Other studies (Mittelmann et al., 2003) evaluated oil content, protein content and grain yield in a group of maize test-crosses under RCBD with three replications. Results showed week association and significant variation for oil content, protein content and grain yield. Deif et al. (2012) set an experiment to study the variability of 14 maize inbred lines and 15 crosses for oil and protein content. Results showed significant differences for protein content and oil content ranging from $8.34 \%$ to $11.60 \%$ and 7.67 to $11.56 \%$, respectively. On the other hand, in crosses protein and oil content ranges from $8.22 \%$ to $13.94 \%$ and $9.27 \%$ to $11.29 \%$, respectively. The highest values for protein content (13.94\%), oil content $(10.65 \%)$ and grain yield per plant (128.73 g) were reported by a cross.

Previous studies suggested that plant height is strongly associated with maize yield (Hegy et al., 2002; Sangoi et al., 1998; Aldrich et al., 1986), while 100-kernel weight and ear length predict yield components, whereas days to $50 \%$ silking predicts the maturity time of maize plants (Okporie et al., 2007). Furthermore, maize forage yield is preferred by farmers because it contains sufficient quantities of protein and minerals and possesses high digestibility as compared to other non-legume fodders (Chaudhary et al., 2014). Therefore, Plant height, grain yield, ear length, days to 50\% silking and dry forage yield are among the most important agronomic traits to be assessed and should not be adversely affected in the maize breeding programs. Okporie et al. (2007) investigated 8 maize varieties to find out the correlation of increasing oil and protein content with five important agronomic parameters viz., plant height, ear height, 100kernel weight, kernel density and days to 50\% silking, under RCBD with 3 replications. They reported an independent association among the traits investigated and concluded that oil and protein content of maize can be increased without adversely affecting these agronomic traits.

Pakistan is not only facing the problem of having low maize yield $\mathrm{ha}^{-1}$ but also the poor quality of corn grain. Therefore, to achieve the goal efforts need to develop high 
yielding maize varieties with an improved percentage of oil and protein which can be obtained by the determination of variability among the local and exotic germplasm to be used in future breeding programs.

The objectives of this study are: (1) to determine variation among selected maize varieties through morphological, biochemical and molecular markers; (2) to determine the association of oil and protein content with selected agronomic markers.

\section{Materials and methods}

The experimental material comprised of 10 open pollinated maize varieties viz., Sadaf, Islamabad Yellow, Agati-2002, SG-2002, Soan-3, Sahiwal-2002, Margala, Rakaposhi, Islamabad white and Kashmir Gold and 8 advance maize lines viz., BS-1, EV-7004 Q, EV-5098, EV-1097, BS-2, EV-6089, EV-6098, and EV-1098. The Seed of 8 open pollinated varieties and 9 advance maize lines were collected from National Agriculture Research Council (NARC) Islamabad and one local variety 'Kashmir Gold' was used as a check. The experiment was carried out using randomized complete block design with three replications at the research area of Faculty of Agriculture, Rawalakot, Department of Plant Breeding and Molecular Genetics. Each plot comprised of two rows each $5 \mathrm{~m}$ in length with a plant to plant distance of $20 \mathrm{~cm}$ and a row to row distance of $75 \mathrm{~cm}$. All recommended agronomic practices were followed to raise an ideal crop. Data on 5 competitive plants of the selected one-meter square area from each plot was recorded on maturity. Nitrogen and phosphorus fertilizers were applied @ 60 and $90 \mathrm{~kg} \mathrm{ha}^{-1}$, respectively. Data was recorded before and after harvesting of the crop for five morphological traits viz., days to $50 \%$ silking, plant height, 1000-grain weight, ear length and dry forage yield and two biochemical traits viz., oil content and protein content. Morphological parameters were recorded by using the standard descriptors formulated by IBPGR (1980). The protein content was determined by the MicroKjeldahl method as described by Pearson (1976). While the oil content was obtained with the help of Soxhlet's extractor as described by Anon (1978).

From the source population two advance maize lines viz., EV-5098, EV-1097, EV6089, two commercial varieties viz., Agaiti-2002, Rakaposhi and a Local Check (Kashmir Gold) with a high percentage of oil and protein were selected and analyzed for total seed protein profile using Sodium Dodecyl Sulphate Polyacrylamide Gel Electrophoresis (SDS-PAGE) as described by Laemmli (1970). The gel picture was taken, uploaded to ImageJ software and the distance covered by protein bands was calculated and scored by assigning + or - sign for the presence or absence of bands, respectively.

Data for agronomic and biochemical traits were submitted to analysis of variance using the GLM procedure of the SAS system v9.2 (SAS Institute, 2007) and the treatment means were compared by the Tukey's test at 5\% level of significance. Correlation associations of oil content and protein content of maize kernel with plant height, days to silking, ear length, 1000-grain weight, and dry forage yield and correlation coefficients were calculated as given by Okpori (2006).

\section{Results}

The mean values for days to silking, plant height, ear length, 1000-grain weight, and dry forage yield are given in Table 2. Data for these morphological characters were 
analyzed statistically and genotypic and phenotypic variance and covariance were estimated (Table 1). Significant differences were observed among maize accessions for days to silking, plant height, ear length, 1000-grain weight and dry forage weight (Table 1). The genotypic and phenotypic variances were significantly different for all the traits (Table 1). Genotypic and phenotypic variability values for days to silking $(0.22 \%$ and $0.23 \%$, respectively), plant height (1.4\% and $1.4 \%$, respectively), ear length ( $0.09 \%$ and $0.10 \%$, respectively), 1000-grain weight (7.4\% and $7.9 \%$, respectively) and dry forage yield $(281.25 \%$ and $326 \%$, respectively) showed less environmental influence on these tested characters.

Table 1. Estimates of parameters of variability for yield and its components

\begin{tabular}{c|c|c|c|c|c|c}
\hline Characters & Mean & Range & $\begin{array}{c}\text { Genotypic } \\
\text { variance }\end{array}$ & $\begin{array}{c}\text { Phenotypic } \\
\text { variance }\end{array}$ & GCV & PCV \\
\hline Days to 50\% silking & 81.9 & $71.5-87.8$ & 17.9 & 18.9 & 0.2 & 0.2 \\
Plant height $(\mathrm{cm})$ & 199.9 & $170-241$ & 274 & 278 & 1.4 & 1.4 \\
Ear length $(\mathrm{cm})$ & 15.35 & $12.8-18$ & 1.3 & 1.6 & 0.1 & 0.1 \\
1000 grain weight $(\mathrm{g})$ & 232.8 & $180.83-345$ & 1717 & 1839 & 7.4 & 7.9 \\
Dry matter yield $\left(\mathrm{kg} \mathrm{ha}^{-1}\right)$ & 12640.3 & $8564-16295$ & 3555051 & 4120678 & 281.3 & 326.0 \\
Oil content $(\%)$ & 5.2 & $2.10-8.40$ & 3.72 & 3.73 & 36.85 & 36.88 \\
Protein content $(\%)$ & 4.80 & $2.07-7.80$ & 3.19 & 3.20 & 37.13 & 37.15 \\
\hline
\end{tabular}

The minimum days to silking were taken by Rakaposhi with an average value of 73 , whereas variety EV-1097 took maximum 86.9 days, similarly, Aguiti-2002 attained maximum plant height of $238.0 \mathrm{~cm}$, whereas variety EV-1097 was short stature variety with $172.6 \mathrm{~cm}$ plant height. Agaiti-2002 and local check attained the maximum ear length with an average of $17.8 \mathrm{~cm}$ and $17.65 \mathrm{~cm}$, respectively, and EV-7004Q attained minimum ear length of $13.10 \mathrm{~cm}$. Maximum grain weight with an average value of $308.8 \mathrm{~g}$ was obtained from Agaiti-2002, whereas the minimum weight of 100-grains was presented by Sahiwal2002 (181.1 g). EV-1098 produced maximum dry matter yield $\left(16190 \mathrm{~kg} \mathrm{ha}^{-1}\right)$, whereas the variety EV-7004Q yielded less dry matter ha ${ }^{-1}$ with an average value of $9342.0 \mathrm{~kg}$.

The mean values for oil content and protein content are given in Table 2. Data for these biochemical characters were analyzed statistically and significant differences were observed among maize varieties for oil content and protein content and genotypic and phenotypic variance and covariance were estimated (Table 1) for oil content $(36.85 \%$ and $36.88 \%$, respectively) and protein content (37.13\% and $37.15 \%$, respectively). Results showed less environmental influence on the traits of oil content and protein content. Maximum values for oil content and protein content were obtained by EV-6089 (8.40\%) and Agaiti-2002 $(11.80 \%)$, respectively. Meanwhile, minimum values were obtained by EV-1098 $(2.10 \%$, $6.06 \%$, respectively). The coefficient of variation (CV \%) for days to silking (1.15), plant height (1.5), ear length (3.15), 1000-grain weight (4.53), dry forage yield (5.95) oil content (2.83) and protein content (1.78) indicates the excellent experimental precision.

From the photograph of the protein gel (photograph not presented) banding pattern drawn and the distance covered by protein bands measured (Table 3). The protein gel expressed nine bands at the marginally variable distance. At the distance of $1 \mathrm{~cm}(10 \mathrm{kDa})$ and $1.6 \mathrm{~cm}(15 \mathrm{kDa})$, all the varieties showed a common band. EV-6089, Rakaposhi and Local check (Kashmir Gold) recorded one band each at the distance of $2.7 \mathrm{~cm}(25 \mathrm{kDa})$. EV-6089 and Local check shared one common band at the distance of $3.1 \mathrm{~cm}(30 \mathrm{kDa})$ in 
the protein profile. Agaiti-2002, EV-5098 and EV-1097 gave one band each travelled the distance of $3.4 \mathrm{~cm}(40 \mathrm{kDa})$. Rakaposhi had two isolated bands at the distance of $4 \mathrm{~cm}(70$ $\mathrm{kDa})$ and $6.4 \mathrm{~cm}(130 \mathrm{kDa})$. Similarly, EV-5098 expressed a solitary band at the distance of $4.8 \mathrm{~cm}(100 \mathrm{kDa})$ in the protein profile. EV-5098 and EV-1097 both had one band each at a distance of $7.3 \mathrm{~cm}(170 \mathrm{kDa})$.

Table 2. Mean values of different morphological traits of maize (Zea mays L.) varieties

\begin{tabular}{|c|c|c|c|c|c|c|c|c|}
\hline SN & Variety & Days to silking & $\begin{array}{l}\text { Plant height } \\
\text { (cm) }\end{array}$ & $\begin{array}{l}\text { Ear length } \\
\text { (cm) }\end{array}$ & $\begin{array}{l}\text { 1000-grain } \\
\text { weight (g) }\end{array}$ & $\begin{array}{l}\text { Dry forage yield } \\
\text { (g) }\end{array}$ & $\begin{array}{c}\text { Protein } \\
\text { content } \\
(\%)\end{array}$ & $\begin{array}{c}\begin{array}{c}\text { Oil } \\
\text { content } \\
(\%)\end{array} \\
\end{array}$ \\
\hline 1 & Rakaposhi & $86.90 \mathrm{~A}$ & $201.5 \mathrm{EF}$ & 14.85 BCDEF & $206.5 \mathrm{CD}$ & $14010.0 \mathrm{ABCDE}$ & $10.11 \mathrm{C}$ & $3.10 \mathrm{EF}$ \\
\hline 2 & Islamabad white & $86.70 \mathrm{AB}$ & $178.0 \mathrm{H}$ & 15.20 BCDEF & $204.7 \mathrm{CD}$ & $14880.0 \mathrm{AB}$ & 7. $97 \mathrm{G}$ & $1.8 \mathrm{G}$ \\
\hline 3 & Sadaf & $85.70 \mathrm{ABC}$ & $197.1 \mathrm{~F}$ & $15.40 \mathrm{BCDE}$ & $234.0 \mathrm{C}$ & 10750.0 FGH & $8.66 \mathrm{~F}$ & $3.30 \mathrm{EF}$ \\
\hline 4 & Islamabad yellow & $85.05 \mathrm{ABC}$ & $196.5 \mathrm{~F}$ & $16.50 \mathrm{AB}$ & $214.3 \mathrm{CD}$ & $9884.0 \mathrm{GH}$ & $9.26 \mathrm{DE}$ & $4.50 \mathrm{C}$ \\
\hline 5 & EV-7004 Q & $85.00 \mathrm{ABC}$ & 203.3 DE & $13.10 \mathrm{G}$ & $274.5 \mathrm{AB}$ & $9342.0 \mathrm{H}$ & $8.10 \mathrm{G}$ & $4.00 \mathrm{D}$ \\
\hline 6 & BS-2 & $84.85 \mathrm{ABC}$ & $177.3 \mathrm{H}$ & $13.80 \mathrm{EFG}$ & $202.7 \mathrm{CD}$ & $12260.0 \mathrm{CDEFG}$ & $9.47 \mathrm{D}$ & $3.97 \mathrm{D}$ \\
\hline 7 & BS-1 & $84.45 \mathrm{ABCD}$ & $189.0 \mathrm{G}$ & 15.20 BCDEF & $208.8 \mathrm{CD}$ & 12140.0 DEFG & $6.47 \mathrm{I}$ & $1.40 \mathrm{GH}$ \\
\hline 8 & Local check (XY) & $83.90 \mathrm{ABCD}$ & $219.9 \mathrm{~B}$ & $17.65 \mathrm{~A}$ & $298.8 \mathrm{AB}$ & $14200.0 \mathrm{ABCDE}$ & $11.27 \mathrm{~B}$ & $6.20 \mathrm{AB}$ \\
\hline 9 & EV-6089 & $83.50 \mathrm{BCD}$ & $212.7 \mathrm{C}$ & $16.30 \mathrm{ABC}$ & $300.9 \mathrm{AB}$ & $11190.0 \mathrm{FGH}$ & $11.17 \mathrm{~B}$ & $6.37 \mathrm{~A}$ \\
\hline 10 & SG-2002 & $83.40 \mathrm{BCD}$ & $220.1 \mathrm{~B}$ & $13.70 \mathrm{FG}$ & $278.8 \mathrm{AB}$ & $9984.0 \mathrm{GH}$ & $6.70 \mathrm{I}$ & $3.50 \mathrm{E}$ \\
\hline 11 & Sahiwal-2002 & $82.80 \mathrm{CDE}$ & 204.4 DE & $16.45 \mathrm{AB}$ & $181.1 \mathrm{D}$ & 11040.0 FGH & $10.20 \mathrm{C}$ & $0.47 \mathrm{I}$ \\
\hline 12 & Margala & $82.65 \mathrm{CDE}$ & $188.3 \mathrm{G}$ & 14.85 BCDEF & $198.5 \mathrm{CD}$ & $12700.0 \mathrm{BCDEF}$ & $6.17 \mathrm{~J}$ & $1.17 \mathrm{H}$ \\
\hline 13 & EV-6098 & $81.30 \mathrm{DE}$ & $208.3 \mathrm{CD}$ & 14.50 DEFG & $269.5 \mathrm{~B}$ & $14440.0 \mathrm{ABCD}$ & $7.30 \mathrm{H}$ & $2.87 \mathrm{~F}$ \\
\hline 14 & EV-5098 & $79.80 \mathrm{E}$ & $187.4 \mathrm{G}$ & $15.40 \mathrm{BCDE}$ & $208.4 \mathrm{CD}$ & $14700.0 \mathrm{ABC}$ & $10.10 \mathrm{C}$ & $3.97 \mathrm{D}$ \\
\hline 15 & EV-1097 & $75.00 \mathrm{~F}$ & $172.6 \mathrm{H}$ & $15.85 \mathrm{BCD}$ & $186.0 \mathrm{D}$ & $11750.0 \mathrm{EFGH}$ & $9.17 \mathrm{E}$ & $4.80 \mathrm{C}$ \\
\hline 16 & EV-1098 & $75.00 \mathrm{~F}$ & $199.6 \mathrm{EF}$ & 15.00 BCDEF & $214.4 \mathrm{CD}$ & $16190.0 \mathrm{~A}$ & $6.07 \mathrm{~J}$ & $0.10 \mathrm{I}$ \\
\hline 17 & Agaiti-2002 & $74.80 \mathrm{~F}$ & $238.0 \mathrm{~A}$ & $17.75 \mathrm{~A}$ & $308.3 \mathrm{~A}$ & $14980.0 \mathrm{AB}$ & $11.76 \mathrm{~A}$ & $5.80 \mathrm{~B}$ \\
\hline 18 & Soan-3 & $73.95 \mathrm{~F}$ & $204.9 \mathrm{DE}$ & 14.75 CDEF & $200.4 \mathrm{CD}$ & 13090.0 BCDEF & $8.70 \mathrm{~F}$ & $3.00 \mathrm{H}$ \\
\hline & $\mathbf{L S D}_{0.05}$ & 2.89 & 9.21 & 1.48 & 5.11 & 2311 & 0.26 & 0.45 \\
\hline & CV (\%) & 1.15 & 1.50 & 3.15 & 4.53 & 5.95 & 1.78 & 2.83 \\
\hline
\end{tabular}

*Means with similar letters are statistically non-significant

Table 3. Tabulated representations of SDS-PAGE results of six maize varieties

\begin{tabular}{c|c|c|c|c|c|c|c}
\hline Distance (cm) & kDa & Agaiti-02 & EV-5098 & EV-1097 & EV-6089 & Rakaposhi & Local check \\
\hline 1 & 10 & + & + & + & + & + & + \\
1.6 & 15 & + & + & + & + & + & + \\
2.7 & 25 & - & - & - & + & + & + \\
3.1 & 30 & - & - & - & + & - & + \\
3.4 & 40 & + & + & + & - & - & - \\
4 & 70 & - & - & - & - & + & - \\
4.8 & 100 & - & + & - & - & - & - \\
6.4 & 130 & - & - & - & - & + & - \\
7.3 & 170 & - & + & + & - & - & - \\
\hline
\end{tabular}

+ Presence of protein band. - Absence of protein band

Almost all the maize varieties from the source population expressed negative or positive but non-significant correlation of oil and protein with agronomic traits viz., days to silking, plant height, ear length, 1000-grain weight and dry forage yield (Table $4 a$ and $4 b$ ). For some traits maize varieties viz., BS-2, Agaiti-2002 and EV-6089, Sahiwal-2002 for days to silking, EV-6089, Islamabad white, EV-1098, Rakaposhi, 
Agaiti-2002, BS-2 and EV-6089 for plant height, Margala, Soan-3, EV-704 Q, SG2002, Soan-3 and Kashmir Gold for ear length, Sadaf, EV-5098, Islamabad yellow, Agaiti-2002 and Sahiwal-2002 for 1000-grain weight, EV-7004 Q and Soan-3 for forage yield, showed positive or negative and significant results.

Table 4a. Correlation (r) between oil content and five morphological traits

\begin{tabular}{c|c|c|c|c|c}
\hline Varieties & Dry matter & $\begin{array}{c}\text { Ear length } \\
(\mathbf{c m})\end{array}$ & $\begin{array}{c}\text { Plant height } \\
(\mathbf{c m})\end{array}$ & Days to silking & $\begin{array}{c}\text { 1000-grain } \\
\text { weight }\end{array}$ \\
\hline Sadaf & -0.705 & -0.592 & 0.461 & -0.165 & $-0.982^{*}$ \\
BS-1 & 0.279 & 0.277 & -0.277 & 0.867 & 0.287 \\
Islamabad yellow & -0.260 & -0.397 & 0.705 & 0.962 & $0.986^{*}$ \\
Agaiti-2002 & 0.608 & 0.719 & 0.798 & $-0.984^{*}$ & 0.602 \\
EV-7004 Q & $1.000^{* *}$ & -0.348 & 0.721 & 0.327 & 0.146 \\
EV-5098 & -0.321 & 0.619 & 0.823 & -0.741 & $-1.000^{*}$ \\
EV-1097 & -0.849 & 0.645 & -0.549 & 0.902 & -0.189 \\
BS-2 & -0.371 & 0.037 & 0.915 & $1.000^{* *}$ & 0.655 \\
Margala & 0.191 & $0.973 *$ & 0.856 & 0.886 & -0.756 \\
EV-6089 & -0.602 & -0.786 & $0.975 *$ & $-0.990 *$ & -0.735 \\
Islamabad white & -0.710 & -0.803 & $0.999 * *$ & 0.560 & -0.350 \\
EV-6098 & 0.951 & 0.189 & $1.000^{* *}$ & 0.911 & -0.800 \\
Rakaposhi & -0.716 & -0.209 & $0.999 * *$ & -0.795 & -0.867 \\
SG-2002 & 0.405 & 0.803 & -0.674 & 0.444 & -0.884 \\
EV-1098 & -0.965 & -0.866 & $-0.995^{* *}$ & 0.972 & 0.822 \\
Soan-3 & -0.416 & $-0.998^{* *}$ & -0.873 & 0.406 & -0.956 \\
Sahiwal-2002 & 0.294 & -0.397 & -0.669 & 0.842 & $0.979 *$ \\
Local check (Kashmir Gold) & -0.472 & 0.914 & -0.511 & 0.812 & -0.588 \\
\hline
\end{tabular}

Table $4 \boldsymbol{b}$. Correlation (r) between protein content and morphological traits

\begin{tabular}{c|c|c|c|c|c}
\hline Varieties & Dry matter & Ear length & Plant height & Days to silking & $\begin{array}{c}\text { 1000-grain } \\
\text { weight }\end{array}$ \\
\hline Sadaf & -0.256 & -0.916 & 0.843 & 0.350 & -0.945 \\
BS-1 & -0.627 & -0.629 & 0.629 & 0.905 & 0.949 \\
Islamabad yellow & 0.612 & 0.721 & -0.376 & -0.782 & -0.846 \\
Agaiti-2002 & $0.988^{*}$ & 0.041 & $0.993 *$ & -0.836 & -0.116 \\
EV-7004 Q & -0.409 & $0.999 * *$ & 0.350 & 0.737 & -0.966 \\
EV-5098 & -0.659 & 0.371 & -0.904 & 0.952 & 0.500 \\
EV-1097 & 0.807 & -0.700 & 0.485 & -0.932 & 0.115 \\
BS-2 & -0.664 & 0.374 & $0.998^{* *}$ & 0.931 & 0.359 \\
Margala & 0.477 & $0.998^{* *}$ & 0.661 & 0.706 & -0.918 \\
EV-6089 & 0.481 & 0.866 & -0.933 & $1.000 * *$ & 0.824 \\
Islamabad white & -0.954 & -0.439 & 0.865 & 0.878 & -0.742 \\
EV-6098 & -0.919 & -0.277 & $-0.995 * *$ & -0.945 & 0.742 \\
Rakaposhi & -0.519 & -0.447 & 0.956 & -0.922 & -0.964 \\
SG-2002 & -0.343 & $0.992^{*}$ & 0.027 & 0.941 & -0961 \\
EV-1098 & -0.641 & 0.091 & -0.329 & 0.620 & -0.172 \\
Soan-3 & -0.309 & $-0.985 *$ & -0.923 & 0.298 & $-0.983 *$ \\
Sahiwal-2002 & -0.110 & 0.000 & -0.319 & $0.987 *$ & 0.818 \\
Local check (Kashmir & 0.158 & $-0.997 * *$ & 0.764 & -0.576 & 0.820 \\
Gold) & & & &
\end{tabular}




\section{Discussion}

Morphological comparisons were made to know the extent of variation among maize varieties under investigation to estimate the genetic diversity. Statistical analysis of the data reflected a high level of variation for all the morphological traits. This is in agreement with the results reported by Hussain et al. (2011) who have screened the same maize varieties and reported the wide range of variation for all the morphological markers used and reported values ranged from 69 to 84 and 145 to 205 for days to silking and plant height, respectively. Present results for days to silking, plant height and ear length also showed resemblance with the findings of Koirala and Gurung (2002), who reported a significant amount of variability for days to silking, plant height and ear length. Koirala and Gurung (2002) recorded days to silking varied from 72 to 77 days, 198 to $230.0 \mathrm{~cm}$ plant height and a similar range of values for ear length. Similar findings were also reported by Borras et al. (2007), Baqa et al. (2014) and Ghimire and Timsina (2015) for days to silking. Present investigation showed that 1000-grain weight results were closer to the findings of Koirala and Gurung (2002) and Sabeena and Dar (2005), who reported a wide range of variability for 1000 grain weight, values ranged from 340 to $325 \mathrm{~g}$. Similarly, significant variations for grain yield were reported by other investigations (Mubeen et al., 2015; Charles et al., 2013; Adebayo and Menkir, 2015). High variability for important agronomic traits, i.e. days to silk, plant height, ear length, 1000-kernel weight and grain yield in our investigation was also supported by the results of previous studies (Sonmez, 2018; Iqbal et al., 2015; Shrestha, 2013; Ranatunga et al., 2009; Miguel et al., 2008; Ihsan et al., 2005; Beyene et al., 2005; Dijak et al., 1999). Results for dry matter yield in this study do not resemble with the findings of Sabeena and Dar (2005), who reported the values ranged from 8150 to $12000 \mathrm{~kg} \mathrm{ha}^{-1}$ for this trait. These findings also show deviation with the findings of Koirala and Gurung (2002), who observed the maximum dry forage yield of $14000 \mathrm{~kg}$ $\mathrm{ha}^{-1}$. Genotypic and phenotypic variances are presented in Table 1. For all the traits studied, genotypic and phenotypic variances were significant, which is a piece of evidence that variability within the maize varieties is sufficiently divergent and constitutes potential candidate varieties on which improvement program can be initiated.

The values for oil content and protein content were significantly different and varied between $0.10 \%-6.40 \%$ and $6.06 \%-11.80 \%$, respectively. The results were in clear agreement with the previous findings reported significantly different percentage of oil and protein values ranged from $3.77 \%$ to $11.56 \%$ and $5.7 \%$ to $12.08 \%$, respectively (Sonmez, 2018; Deif et al., 2012; Seiam and Khalifa, 2007; Mittelmann et al., 2003; Singh et al., 2005). Varieties in the present study showed less percentage of oil content as compared to the previous studies. This difference may be due to the environmental factors and plant growth conditions which could modify the percentage of oil percentage (Villalobos et al., 1996).

Use of SDS-PAGE markers for the determination of variability and identification of varieties by extensive study of seed storage protein in many crop species became an efficient tool (Shah et al., 2003; Tawab, 2004; Anjali and Sanjay, 2012; Iqbal et al., 2014). In this study, the variability within selected varieties was confirmed by molecular investigations on the basis of gene product extracted from the seed of six maize accessions using SDS-PAGE markers. At the distance of $1 \mathrm{~cm}(10 \mathrm{kDa})$ and 1.6 $\mathrm{cm}(15 \mathrm{kDa})$ similar varieties could be an indication of their evolutionary interrelationship. EV-6089, Rakaposhi and Local check (Kashmir Gold) recorded one 
band each at the distance of $2.7 \mathrm{~cm}(25 \mathrm{kDa})$ in the protein gel which indicated their similar genetic makeup. EV-6089 and Local check were different from the others as they shared one common band at the distance of $3.1 \mathrm{~cm}(30 \mathrm{kDa})$ in the protein profile. Agaiti-2002, EV-5098 and EV-1097 gave one band each travelled the distance of 3.4 $\mathrm{cm}(40 \mathrm{kDa})$ in the protein gel which showed their genetic resemblance as well as evidence that these varieties could have some common heritage. Rakaposhi had two isolated bands at the distance of $4 \mathrm{~cm}(70 \mathrm{kDa})$ and $6.4 \mathrm{~cm}(30 \mathrm{kDa})$ that showed Rakaposhi is genetically different from all other varieties studied so far. Similarly, EV5098 expressed a solitary band at a distance of $4.8 \mathrm{~cm}(100 \mathrm{kDa})$ in the protein profile and showed that EV-5098 has a different genetic background as compared to other varieties studied so far. EV-5098 and EV-1097 both had one band each at a distance of $7.3 \mathrm{~cm}(170 \mathrm{kDa})$ which indicated that these maize accessions have some common genes and genetically they are different from other varieties. Similar results were reported in other investigations which exploited high level of genetic variability among studied germplasm and revealed that some bands are scored by all varieties and some bands shared by one or more than one variety (Khan et al., 2014; Osman et al., 2013; Verma, 2006; Laura, 2006; Haider, 2002; Tubajika, 2001; Gorinstein, 1999). In the present study, $22 \%$ of total visible protein bands were monomorphic and $78 \%$ were polymorphic. Results are in clear agreement with other findings (Vivodik et al., 2016; Iqbal et al., 2014; Rashed et al., 2010) which reported a wide range of variability among maize germplasm and recorded $31 \%$ to $39 \%$ monomorphic and $61 \%$ to $65 \%$ polymorphic protein bands.

The positive or negative and significant results of correlation suggest that an increase in oil content of maize can adversely affect the important agronomic traits. But these results are negligible as not even a single genotype has significant results for all the traits studied and only a few lines showed significant results for few traits. Since no significant relationship existed in the majority of remaining varieties of the source population, it indicates that high oil maize can be bred without adversely affecting the studied agronomic traits. Similar results were reported by Okporie and Oselebe (2007), Okporie and Obi (2002), Obi and Onish (1994) and Rajni et al. (1983). For 1000-grain weight, the present finding was contrary to the work reported by Okporie and Obi (2002) and Obi and Onish (1994), who found oil content to be positively and significantly correlated with 1000 -grain weight.

Results of some morphological and biochemical traits deviate from the previous findings. This departure may be due to the environmental factors, variable sample size, and source population. For reliable detection of contrasted varieties usually experiments were performed in two or more consecutive years but the present experiment has not been repeated in consecutive years because Hussain et al. (2011) have previously evaluated the performance of the same varieties which have been screened in the present study and they also recorded significant differences for all the morphological traits studied and reported that these varieties had a wide genetic background, therefore, the results of the present investigation have sufficient and the real scientific interest.

\section{Conclusion}

In this study, morphological and biochemical markers confirmed a high level of variability among all the maize varieties investigated. Similarly, molecular markers (SDS-PAGE) also confirmed the wide range of variation among selected maize 
varieties. The variability can be used in future breeding programs to improve maize varieties. Further, results showed non-significant association between oil and protein content with days to $50 \%$ silking, plant height, ear length, 1000-grain weight and dry forage yield, which indicated that oil and protein content that are among the most important and desirable traits of maize grain could be increased by using effective breeding methods without negatively affecting the important agronomic traits studied. Finally, recurrent selection and hybrid breeding might be recommended for developing high yielding maize varieties with the improved percentage of oil content and protein content.

Acknowledgements. We are thankful to NARC Islamabad, HEC Pakistan and Department of Food Science and Technology, University of Poonch for their financial and technical support.

Author contribution. All authors contributed equally.

Conflict of interests. The authors declare that they have no conflict of interests.

\section{REFERENCES}

[1] Adebayo, M. A., Menkir, A. (2015): Assessment of hybrids of drought tolerant maize (Zea mays L.) inbred lines for grain yield and other traits under stress managed conditions. - Nigerian Journal of Genetics 20: 1-5.

[2] Aldrich, S. R., Scott, W. O., Hoeft, R. G. (1986): Modern Maize Production. 3th Ed. - A and L Publications, Inc., Champaign, Illinois.

[3] Anjali, C., Sanjay, C. (2012): Genetic diversity estimation of maize cultivars based on protein profiles in different conditions. - Indian Journal of Agriculture and Biochemistry 25: 52-56.

[4] FAOSTAT (2012): Food and Agricultural commodities production. - Food and Agriculture Organization of the United Nations. http://faostat.fao.org/site/339/default.aspx.

[5] Anon (1978): Determination of Oil in Feeding Stuffs. Laboratory Manual. - Department of Animal Science, University of Nigeria, Nsukka.

[6] Baqa, S., Haseeb, A., Ahmed, M., Ahmed, A. (2014): Evaluation of growth of different maize marieties in field under the climatic conditions of Peshawar. - Journal of Natural Sciences Research 4: 22-27.

[7] Berner, D. K., King, J. G., Singh, B. B. (2006): Striga research and control. A prospective from Africa. - Plant Disease 79: 652-660.

[8] Beyene, Y., Botha, A. M., Myburg, A. A. (2005): A comparative study of molecular and morphological method of describing genetic relationships in traditional Ethiopian highland maize. - African Journal of Biotechnology 4: 586-595.

[9] Borras, L., Westgate, M. E., Astini, J. P., Echarte, L. (2007): Coupling time to silking with plant growth rate in maize. - Field Crops Research 102: 73-85.

[10] Charles, M. K., Fredrick, N. M., George, O. A., Odongo, O. M. (2013): Genetic variability analysis for growth and yield parameters in double cross maize (Zea mays L.) genotypes in Kitale County of Kenya. - Journal of Plant Breeding and Genetics 01: 7-11.

[11] Chaudhary, D. P., Jat, S. L., Kumar, R., Kumar, A., Kumar, B., (2014): Fodder Quality of Maize: Its Preservation. - In: Chaudhary, D. P. et al. (eds.) Maize: Nutrition Dynamics and Novel Uses. Springer, New Delhi.

[12] Deif, A. M. H., Mekki, B. B., Mostafa, E. A. H., Esmail, R. M., Khattab, S. A. M. (2012): The genetic relationship between proteins, oil and grain yield in some maize hybrids. World Journal of Agricultural Sciences 8: 43-50. 
[13] Dijak, M., Modarres, A. M., Hamilton, R. I., Dwyer, L. M., Stewart, D. W., Mather, D. E., Smith, D. L. (1999): Leafy reduced-stature maize hybrids for short- season environments. - Crop Science 39: 1106-1110.

[14] Farooq, O. (2013): Agriculture. - Pakistan Economic Survey. Government of Pakistan. http://finance.gov.pk/survey_1213.html.

[15] Ghimire, B., Timsina, D. (2015): Analysis of yield and yield attributing traits of maize genotypes in Chitwan, Nepal. - Scrutiny International Research Journal of Agriculture, Plant Biotechnology and Bio Products 2: 153-162.

[16] Gorinstein, S., Jaramillo, N., Medina, O., Rogriques, W., Tosello, G., Paredes, O. (1999): Evaluation of some cereals, plants and tubers through protein composition. - Journal of Protein Chemistry 18: 687-693.

[17] Haider, A., Shanshoury, A. (2002): Variation of storage proteins and isozymes within maize inbred lines. - Biologia Plantarum 43: 199-203.

[18] Hegyi, G. Z., Pok, I., Kizmus, L., Zsubori, Z., Nagy, E., Marton, L. C. (2002): Plant height and height of the main ear in maize (Zea Mays L.) at different locations and different plant densities. - Acta Agronomica Hungarica 50: 75-84.

[19] Hussain, N., Khan, Y., Baloch, M. S. (2011): Screening of mazie varieties for grain yield at Dera Ismail Khan. - Journal of Animal and Plant Science 21: 626-628.

[20] IBPGR (1980): Maize Descriptors. - Food and Agriculture Organization, The International Board for Plant Genetic Resources, Rome, pp. 6-8.

[21] Iqbal, J., Shinwari, Z. K., Rabbani, M. A. (2014): Investigation of total seed storage proteins of Pakistani and Japanese maize (Zea Mays L.) through SDS-PAGE markers. Pakistan Journal of Botany 46: 817-822.

[22] Iqbal, J., Shinwari, Z. K., Rabbani, M. A. (2015): Maize (Zea Mays L.) Germplasm agromorphological characterization based on descriptive, cluster and principal component analysis. - Pakistan Journal of Botany 47: 255-264.

[23] Ihsan, H., Khalil, I. H., Rahman, H., Iqbal, M. (2005): Genotypic variability for morphological and reproductive traits among exotic maize hybrids. - Sarhad Journal of Agriculture 21: 599-602.

[24] Kariuki, J. K., Githiri, S. M., Wesonga, J. M., Tesfamichael, T. S. (2016): Assessment of variation in agro-morphological traits in M3 and M4 maize lines. - International Journal of Agronomy Agriculture Rresearch 9: 147-161.

[25] Khan, S. A., Iqbal, J., Khurshid, H., Saleem, N., Rabbani, M. A., Zia, M., Shinwari, Z. K. (2014): The extent of intra-specific genetic divergence in Brassica napus L. population estimated through various agro-morphological traits. - European Academic Research 2: 2255-2275.

[26] Koirala, R., Gurung, D. (2002): Heterosis and combining ability of seven yellow maize populations in Nepal. - Asian Regional Maize Workshop, Bangkok, Thailand, August, 58.

[27] Laemmli, U. K. (1970): Cleavage of structural proteins during assembly of head of bacetiophage 14. - Nature 227: 680-685.

[28] Laura, M. M., Paulo, A. (2006): Characterization of different maize varieties using SDSPAGE. - Science of Agricultural Genetics 3: 25-27.

[29] Li, J. S., Vassal, S. K. (2004): Quality Protein Maize. - In: Wrigley, C., Walker, C. E. (eds.) Encyclopedia of Grain Science. Elsevier, Amsterdam, pp. 212-216.

[30] Miguel, C., Simoes, M., Oliveira, M. M., Rocheta, M. (2008): Envelope-like retrotransposons in the plant kingdom: evidence of their presence in gymnosperms (Pinus pinaster). - Journal of Molecular Evolution 67: 517-525.

[31] Mittelmann, A., José, B. M. F., Gustavo, J. M. M. L., Claudete, H. K., Ricardo, T. T. (2003): Potential of the ESA23B maize population for protein and oil content improvement. - Scientia Agricola 60: 319-327. 
[32] Mubeen, S., Rafique, M., Munis, M. F. H., Chaudhary, H. J. (2015): Study of southern corn leaf blight (SCLB) on maize genotypes and its effect on yield. - Journal of the Saudi Society of Agricultural Sciences 16: 210-217.

[33] Vojka, B., Nikolic, A., Andjelkovic, V., Kovacevic, D., Filipovic, M., Vasic, V., Drinic, S. M. (2016): UPOV morphological versus molecular markers for maize inbred lines variability determination. - Chilean Journal of Agricultural Research 76: 417-426.

[34] Obi, I. U. (1991): Maize its Agronomy, Diseases, Pest and Food Values. - Optimal Computers Solutions Ltd., Enugu, Nigeria.

[35] Obi, I. U., Onysishii, G. C. (1994): Development of high protein population maize from two cycles of reciprocal recurrent selection. - Journal of Agricultural Research 11: 63-68.

[36] Okporie, E. O. (2006): Statistics for Agricultural and Biological Sciences. - Chestun Agency Limited, Enugu, Nigeria.

[37] Okporie, E. O., Obi, I. U. (2002): Estimation of genetic gains in protein and oil of eight populations of maize after three cycles of reciprocal recurrent selection. - Journal of Science and Agricultural Food Technology 2: 40-45.

[38] Okporie, E. O., Oselebe, H. O. (2007): Correlation of protein and oil contents with five agronomic traits of maize after three cycles of reciprocal recurrent selection. - World Journal of Agricultural Sciences 3: 639-641.

[39] Osman, G., Munshi, A., Altf, F., Mutawie, H. (2013): Genetic variation and relationships of Zea mays and Sorghum species using RAPD-PCR and SDS-PAGE of seed proteins. African Journal of Biotechnology 12: 4269-4276.

[40] Pearson, D. (1976): The Chemical Analysis of Foods. 7th Ed. - Churchill Livingstone Pub. Co., London and New York.

[41] Rajni, R., Sarkar, D. K., Singh, R. (1983): Correlations and regressions among oil content, grain yield and yield components in maize. - Indian Journal of Agriculture Research 11: 63-68.

[42] Ranatunga, M. A. B., Meenakshisundaram, P., Arumungachamy, S., Maheswaran, M. (2009): Genetic diversity of maize (Zea mays L.) inbreds determined with morphomeric traits and simple sequence repeat markers. - Maydica 54: 113-123.

[43] Rashed, M. A., Deif, A. M. H., Atta, A. H., Mohamed, F. I., Mahmoud, F. E. (2010): Protein fingerprinting and heat shock proteins detection in some maize inbred lines (Zea mays L.). - Journal of Genetic Engineering and Biotechnology 8: 1-7.

[44] Sabeena, N., Dar, Z. (2005): Genetic divergence among local maize cultivars of Kashmir Valley. - S. K. University of Agriculture Sciences \& Technology of Kashmir. K. D. Research Station.

[45] Sangoi, L., Salvador, R. J. (1998): Influence of plant height and of leaf number on maize production at high plant densities. - Pesquisa Agropecuária Brasileira 33: 297-306.

[46] SAS, I. (2007): The SAS System for Windows, Version 9.2. - SAS Institute Inc., Cary.

[47] Seiam, M. A., Khalifa, K. I. (2007): Heterosis and phenotypic correlation for oil, protein and starch content in 81 maize inbreds, hybrids and populations. - Egyptian Journal of Plant Breeding 11: 209-221.

[48] Shah, A. H., Khan, M. F., Khaliq, A. (2003): Genetic characterization of some maize (Zea mays L.) varieties using SDS-PAGE. - Asian Journal of Plant Sciences 2: 11881191.

[49] Shrestha, J. (2013): Agro-morphological characterization of maize inbred lines. - Sky Journal of Agriculture Research 2: 85-87.

[50] Singh, P., Sain, D., Dwivedi, V. K., Kumar, Y., Sangwan, O. (2005): Genetic divergence studies in maize (Zea mays L.). - Annals of Agriculture Biological Research 10: 43-46.

[51] Sonmez, C. (2018): Effect of phosphorus fertilizer on some yield components and quality of different anise (pimpinella anisum 1.) populations. - Turkish Journal of Field Crops 23: 100-106. 
[52] Sreckov, Z., Nastastic, A., Bocanski, J., Djalovic, I., Vukosavljev, M., Jockovic, B. (2011): Correlation and path analysis of grain yield and morphological traits in test-cross populations of maize. - Pakistan Journal of Botany 43: 1729-1731.

[53] Tawab, A. Y. M. (2004): Molecular markers of some maize genotypes. - Ph.D. Thesis. Faculty of Agriculture, Ain Shams University, Egypt.

[54] Tubajika, K., Damann, K. (2001): Sources of resistance to aflatoxin production in maize. - Journal of Agricultural and Food Chemistry 49: 2652-2656.

[55] Uguru, M. I. (2005): Crop genetics and Breeding. Revised Ed. - Epharata Press, Nsukka, Enugu State, Nigeria.

[56] Verma, V. L. K., Reddy, N. M., Keshavulu, K., Ankaiah, R. (2006): Characterization of maize genotypes through SDS-PAGE. - Crop Research Hisar 30: 124-27.

[57] Vivodik, M., Galova, Z., Balazova, Z., Petrovicova, L., Hlozakova, T. K. (2016): Genetic variation and relationships of old maize genotypes (Zea mays L.) detected using SDSPAGE. - Potravinarstvo 10: 532-536.

[58] Villalobos, D. F., Hall, A. J., Ritchie, J. T., Orgaz, F. (1996): A development, growth and yield model of the sunflower crop. - Agronomy Journal 88: 403-415.

[59] Zaidi, S. M. H. (2014): Edible oil imports in Pakistan. - South Asian Journal of Management Sciences 8: 1-8. 